\title{
Renal Cell Carcinoma with Duodenal Metastasis: A Rare Presentation
}

\author{
Sajal Goel ${ }^{1 *}$, Deepak Kumar Mittal ${ }^{1}$, Pankaj Sharma ${ }^{2}$ and Vineeta V Batra ${ }^{3}$ \\ ${ }^{1}$ Department of Clinical Oncology, Delhi State Cancer Institutes, India \\ ${ }^{2}$ Department of Radiology, Delhi State Cancer Institutes, India \\ ${ }^{3}$ Department of Pathology, GB Pant Hospital, India
}

Submission: : June 26, 2019; Published: July 23, 2019

*Correspondence Author: Dr Sajal Goel, Ex Senior Resident, Department of Clinical Oncology, Delhi State Cancer Institutes (GNCT of Delhi), Dilshad Garden, Delhi -110095, India

\begin{abstract}
Renal cell carcinoma commonly metastasizes to different organs. The metastasis to duodenum is rare and few cases have been reported till date. We hereby report a case of renal cell carcinoma that presented with abdominal pain after one year of treatment completion. Whole Body PET Scan found a metabolically active lesion in duodenum that was missed on Ultrasound whole abdomen. ERCP guided biopsy reported it as metastatic adenocarcinoma. Immunohistochemistry was conclusive. He was staged as Metastatic Renal Cell Carcinoma Stage IV and started on oral tyrosine kinase inhibitor therapy. Metastasis from renal cell cancer should be suspected in a treated patient who presents late with abdominal pain. A complete evaluation and appropriate management are warranted. Early detection helps in planning further therapy.
\end{abstract}

Keywords: Renal cell carcinoma; Duodenum; Metastatic adenocarcinoma

Abbreviations: Renal Cell Carcinoma (RCC); Tyrosine Kinase Inhibitor (TKI)

\section{Introduction}

Renal cell carcinoma (RCC) is a notorious malignancy with variable metastatic sites and clinical patterns. Even the bowel is not spared and around 7\% cases metastasize to small intestine [1]. The involvement of duodenum is a rare phenomenon and only nineteen cases have been reported in literature till date $[2,3]$. It is fairly expected that duodenal metastasis occurs in presence of widespread visceral and nodal metastases along with disease elsewhere in the body [2]. Solitary duodenal metastasis is presumed to be rare [4]. However, if we look at all the 19 reported cases, 12 had solitary duodenal lesion and seven patients was involved of other organs as well [2,3]. We hereby report a case that had duodenal metastasis one year after being diagnosed and treated for renal cell carcinoma.

\section{Case History}

A fifty-year-old seronegative, chronic tobacco chewer, nonvegetarian, occasional alcoholic, married male farmer was investigated for complaints of bilateral flanks pain and found to have left renal mass. He underwent left-sided nephrectomy along with excision of primary tumour. Postoperative histopathology report proved it as Renal Cell Carcinoma (RCC Clear Cell type) Stage I Grade III. Patient received two cycles of Inj. Dactinomycin
$0.5 \mathrm{mg}$ intravenous over two weeks. Thereafter he received twenty fractions of external beam radiation to flanks over a period of five weeks. He remained disease free for one year.

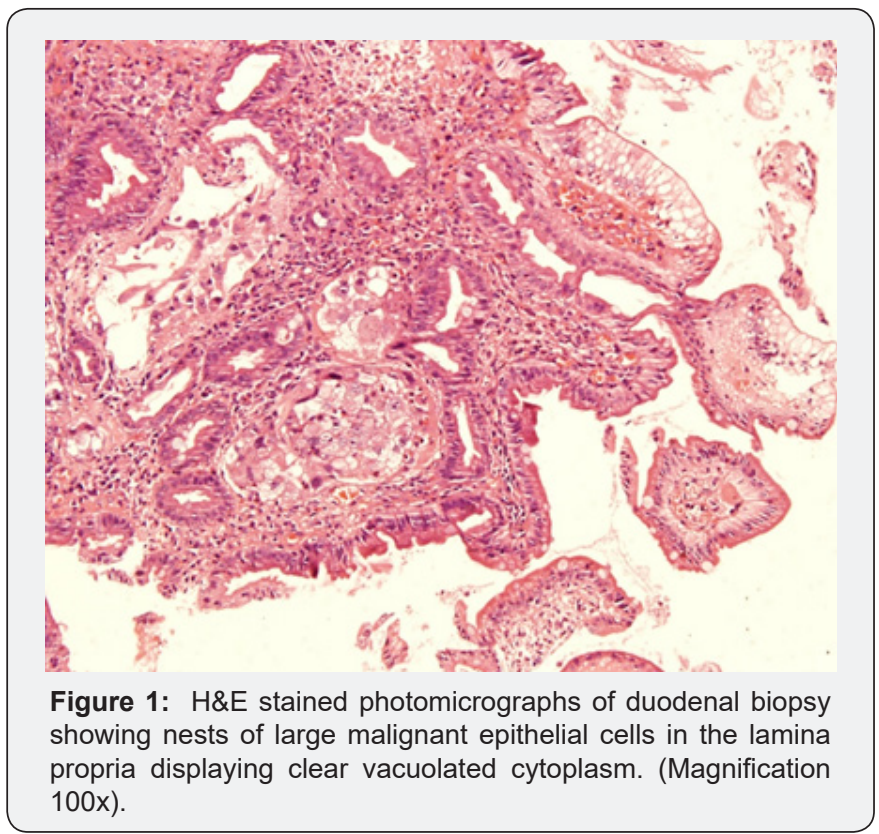




\section{Cancer Therapy \& Oncology International Journal}

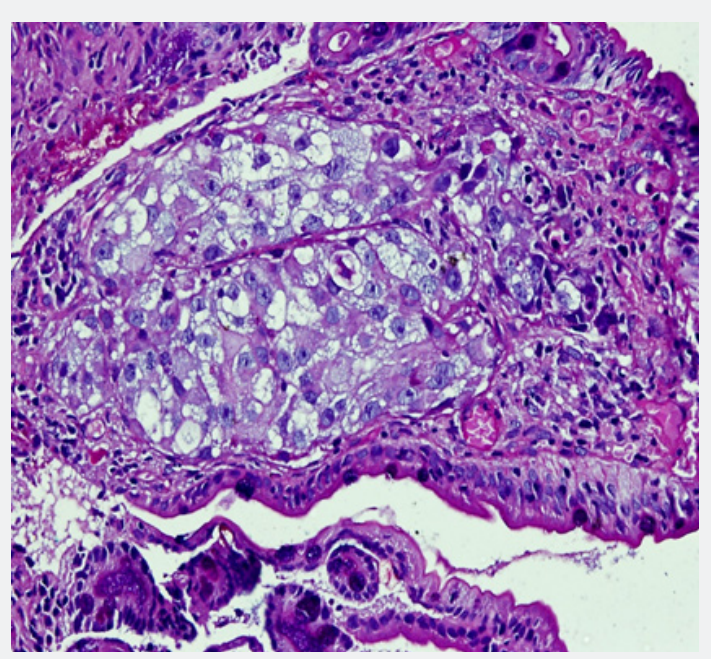

Figure 2: Periodic acid Schiff (PAS) stained photomicrographs treated with diastase showing nests of epithelial cells. The cytoplasmic vacuoles show PAS positive diastase sensitive vacuoles (Magnification 200x).

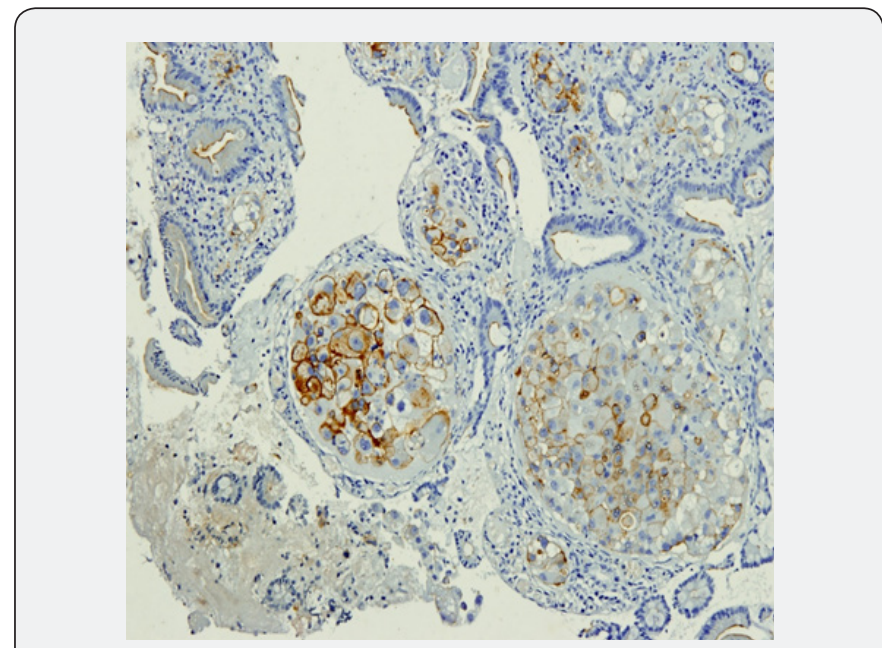

Figure 3: The tumor cells show cytoplasmic membranous positivity for CD 10. (Magnification 100x).

He presented to us with complaints of abdominal pain. On per abdomen examination, nephrectomy scar was healthy. His routine blood investigations were normal. Ultrasound whole abdomen showed peri-portal and peri-pancreatic lymph nodes, left kidney was postoperative and right kidney was normal. Chest X Ray (PA View) was normal. Whole Body PET-CECT scan showed metabolically active nodular infiltrates in right lung, multiple mediastinal, abdominal and bilateral iliac nodes (SUV max 5.6, 9.5, 11.4 and 10.4 respectively); moderate ascites, suspicious diffuse uptake with mucosal irregularity in third part of duodenum and bulkiness in left adrenal gland. Patient underwent Endoscopic Retrograde Cholangiopancreatography (ERCP) \& duodenal biopsy was taken. Histopathological examination (Figure 1) proved it as metastatic adenocarcinoma. Immunohistochemistry showed secondary tumour cells containing PAS positive diastase sensitive vacuoles and positivity for CD 10 (Figures $2 \& 3$ ). So patient was diagnosed finally as a case of Metastatic Left RCC Stage IV with Duodenal metastasis. Patient was started on Tablet Sorafenib $400 \mathrm{mg}$ twice a day that he took for seven days only. He defaulted treatment, was lost to follow-up and did not turn up again or reply on telephonic interrogation.

\section{Discussion}

Majority of cases with duodenal metastasis in an RCC occur in patients older than 50 years age [2]. Of the nineteen cases reported in literature, males outnumber females by a substantial number $(16: 3)[2,3]$. The common presenting symptoms are those of bleeding, anaemia, intestinal obstruction, jaundice and mal absorption [2,3]. Most patients are found to have metastasis within a year after nephrectomy though it can be seen even after several years [5]. This reported patient presented with complaint of abdominal pain more than one year after the treatment of primary site.

RCC can spread intraperitoneally, directly, hematogenously or via lymphatic routes [6]. The disease in our patient is presumed to spread by the latter routes. Duodenal metastases occur in presence of extensive disease elsewhere in the body [2]. This fact is well observed in present patient who also had lung metastases; abdominal, mediastinal and iliac lymph nodes; ascites and bulkiness in left adrenal gland. Most of the patients have received treatment for their primary site earlier in the course of disease [5]. This patient underwent nephrectomy and adjuvant treatment one year earlier prior to presenting with duodenal metastasis. The treatment options in a case of metastatic renal cell carcinoma depend on location and extent of lesion. Patient can be offered palliative surgery, radiotherapy, chemotherapy and immune stimulating agents. We prescribed oral TKI (Sorafenib) in view of metastatic disease. Sorafenib has shown to produce a response rate of $2 \%$ to $10 \%$ with improvement in progression free survival and overall survival. But even after treatment, patients may have a poor overall survival [7]. This case highlights the importance of complete evaluation and appropriate management in a patient who presents with abdominal pain in a known case of renal cell carcinoma. The treating physician and pathologist should diligently raise a high index of suspicion in such cases for early diagnosis and treatment.

\section{Acknowledgement}

The authors acknowledge the contribution of Dr Vineeta V Batra for pathological diagnosis and improvisation of the article.

\section{Conflicting Interest}

Nil.

\section{References}

1. Willis RA (1973) Secondary tumours of the intestines. In the Spread of Tumours in the Human Body ( $3^{\text {rd }}$ edn), Butterworth and Co Ltd 209215, London, England.

2. Bhatia A, Das A, Kumar Y, Kochhar R (2006) Renal cell carcinoma metastasizing to duodenum: a rare occurrence. Diagn Pathol 1: 29. 


\section{Cancer Therapy \& Oncology International Journal}

3. Rustagi T, Rangasamy P, Versland M (2011) Duodenal bleeding from metastatic renal cell carcinoma. Case Rep Gastroenterol 5(1): 249-257.

4. Hashimoto M, Miura Y, Matsuda M, Watanabe G (2001) Concomitant pancreatic and duodenal metastases from renal cell carcinoma: report of a case. Surg Today 31(2): 180-183.

5. Chang WT, Chai CY, Lee KT (2004) Unusual upper gastrointestinal bleeding due to late metastasis from renal cell carcinoma: a case report. Kaohsiung J Med Sci 20(3): 137-141.
6. Pavlakis GM, Sakorafas GH, Anagnostopoulos GK (2004) Intestinal metastases from Renal Cell Carcinoma: a rare cause of intestinal obstruction and bleeding. Mt Sinai J Med 71(2): 127-130.

7. Thyavihally YB, Mahantshetty U, Chamarajanagar RS, Raibhattanavar SG, Tongaonkar HB (2005) Management of renal cell carcinoma with solitary metastasis. World J Surg Oncol 3: 48.

\section{Your next submission with Juniper Publishers will reach you the below assets}

- Quality Editorial service

- Swift Peer Review

- Reprints availability

- E-prints Service

- Manuscript Podcast for convenient understanding

- Global attainment for your research

- Manuscript accessibility in different formats

( Pdf, E-pub, Full Text, Audio)

- Unceasing customer service

Track the below URL for one-step submission https://juniperpublishers.com/online-submission.php 